J. Asiat. Soc. Bangladesh, Sci. 47(2): 121-136, December 2021 DOI: https://doi.org/10.3329/jasbs.v47i2.57276

\title{
SYSTEMATICS OF MODERN BENTHIC FORAMINIFERAL ASSEMBLAGES FROM THE DELTAIC MANGROVE ECOSYSTEM OF SUNDARBANS
}

\author{
TUMPA SAHA ${ }^{1}$ AND SUBROTA KUMAR SAHA ${ }^{2 *}$ \\ ${ }^{1}$ Beach Sand Mineral Exploitation Center, Bangladesh Atomic Energy Commission, \\ Kalatoli, Cox's Bazar-4700, Bangladesh \\ ${ }^{2}$ Department of Geology, University of Dhaka, Dhaka-1000, Bangladesh
}

\begin{abstract}
The contemporary intertidal foraminifera and estuarine environment information were collected from the four sites adjoining the deltaic mangrove environment in the Sundarbans. The marsh zones of the south-western coastal region of Bangladesh were examined for modern benthic foraminifera and to expound on the relationship of the foraminiferal assemblages with the environment. Due to high inaccessibility and remoteness, the taxonomic study of foraminifera and its depositional environment remains largely overlooked in the Sundarbans of Bangladesh. This study includes a detailed survey of depositional environment of these fluvio-deltaic to shallow marine sediments. The seventeen species belonging to fourteen genera representing nine families were recorded from surficial sediment of supratidal, intertidal, and dune environment of Kotka, Jamtala, Kochikhali, and Dimer char area. In the present study, these foraminiferal assemblages are characterized calcareous and agglutinated foraminifera. The Kotka beach is recognized as Nonionina assemblage zone, Jamtala beach designated as Ammonia assemblage zone, Kochikhali as Nonionina assemblage zone and Dimer char as Rosalina-Nonionina-Nonionella assemblage zone. The deposition of foraminifera is restricted to Sundarbans' low to high marsh zone.
\end{abstract}

Keywords: Mangroves, Intertidal foraminifera, Depositional environment, Sediment texture.

\section{Introduction}

Sundarbans, the mangrove ecosystem, is situated in the southernmost part of the GangesBrahmaputra-Meghna (GBM) delta. Late Holocene deposits of the GBM river system formed the riverine delta which is extended across coastal parts of India (West Bengal) and Bangladesh (Stanley and Hait 2000). The fresh water of the Ganges distributaries system and the saline water of the Bay of Bengal make a transition zone in this mangrove ecosystem. Various abiotic factors such as coastal geomorphology, temperature, salinity, tidal amplitude and duration, dissolved oxygen, and nutrients govern the environmental

*Corresponding author: <mail: sks@du.ac.bd>. 
setting of the mangrove ecosystem. Competition, space and food supply are also included in the biotic factors of this ecosystem. In time and space, such macro-level environmental factors of mangroves changes (Ghosh et al. 2014). These changes are well reflected in the distribution of foraminifera. Reconstruction of paleo-environmental conditions may be established by understanding the development of mangrove communities in recent times. This ecosystem consists of various species of fauna and flora. A large number of distributaries of the Ganges and Brahmaputra rivers flow through this ecosystem. A complex network of estuaries, beaches, tidal creeks, tidal inlets, mudflats, sandflats and mangrove swamps exists in this tide-dominated wetland (Mitra et al. 2009). With a high tidal range, high rainfall and high annual sediment load of several rivers debouching sediments into the region makes the study area environmentally dynamic.

Foraminifera constitutes the most diverse group of shelled microorganisms in the modern oceans (Gupta 1999). They are the most ancient and abundant fossils. Also the most efficient rock builders, that's why they are geologically significant (Flint 1899). Sen et al. (2016), in their investigation of benthic foraminifera, noted 15 species from southeast Sundarbans of India. The study area is highly inaccessible because of its geographic location. Moreover, this forest is a water-logged jungle where tigers and other wild animals thrive and intersected by numerous river channels and creeks. So, the taxonomy of modern foraminifera and their distribution in the estuaries of the south-west coastal region of Bangladesh was largely overlooked.

The present research' main objective of the was to systematically describe the recorded foraminiferal species and determine the bio-assemblage constituents and prepare assemblage zone for the overall study area, characterize modern benthic foraminifera, their distribution, assemblage patterns from four sampling sites and investigate the southwestern coastal margin of Bangladesh.

\section{Materials and Methods}

Regionally, the study area covers the South-western coastal margin of Bangladesh. The study area had been chosen for its uniqueness and then to get something new because the micropaleontology of that area was completely unexplored and unknown.

The sampling sites cover an area of almost 16-17 km extending west to east and represent the coastal environments of the Sundarbans forest. The study area belongs to four sampling sites, Kotka $\left(21^{0} 51^{\prime} 24^{\prime \prime} \mathrm{N}, 89^{\circ} 46^{\prime} 16^{\prime \prime} \mathrm{E}\right)$, Jamtala $\left(21^{0} 50^{\prime} 49^{\prime \prime} \mathrm{N}, 89^{\circ} 49^{\prime} 01^{\prime \prime} \mathrm{E}\right)$, 
Kochikhali $\left(21^{0} 51^{\prime} 55^{\prime \prime} \mathrm{N}, 89^{0} 50^{\prime} 12^{\prime \prime} \mathrm{E}\right)$ and Dimer char $\left(21^{0} 51^{\prime} 04^{\prime \prime} \mathrm{N}, 89^{0} 51^{\prime} 01^{\prime \prime} \mathrm{E}\right)$ of the Sundarbans of Bangladesh (Fig. 1).

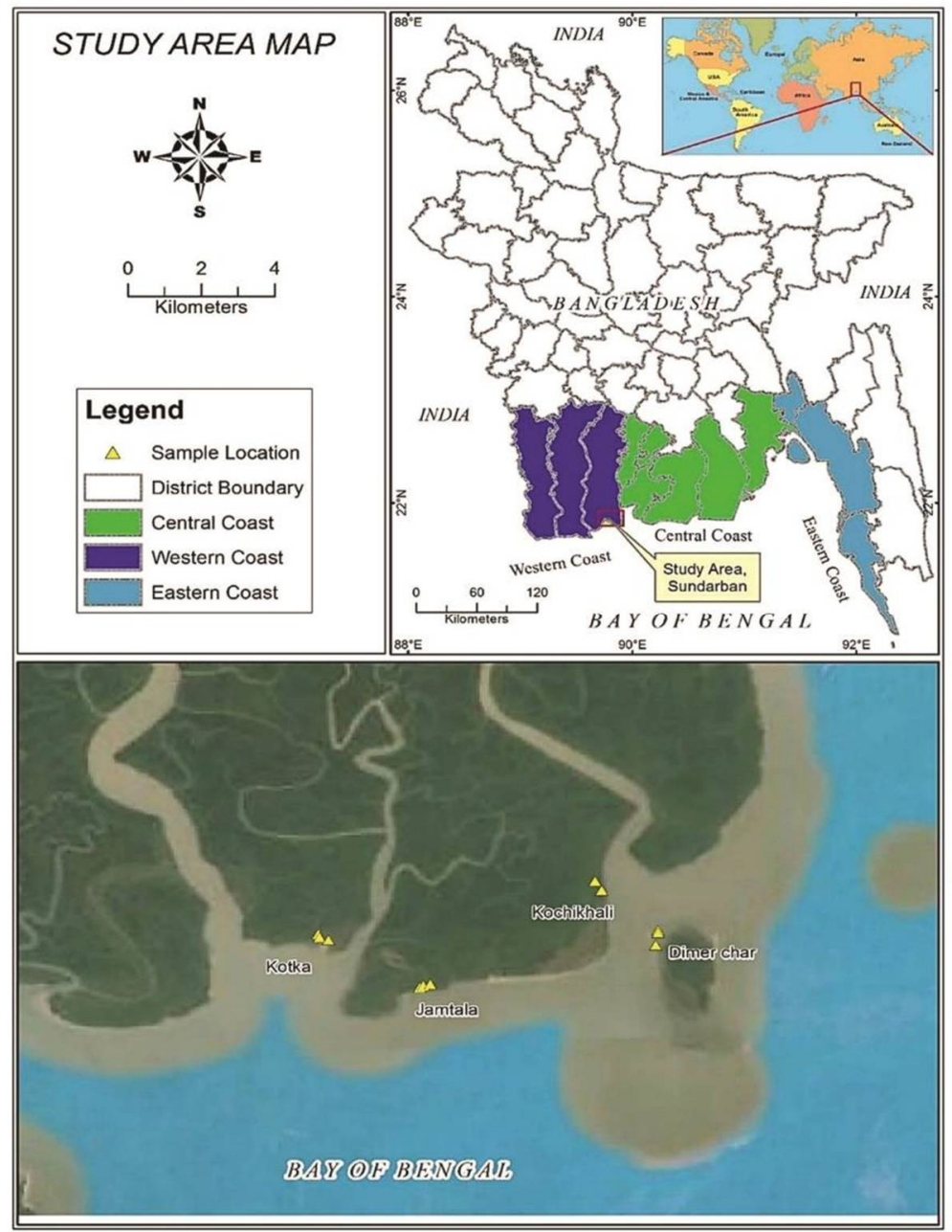

Fig. 1. Location Map of Study area highlighting sampling points.

This area selection is important because there is no such micro-paleontological research in the south-western coastal area of Bangladesh. All samples were carried out during low tide as the water regressed; thereby, the intertidal zone was exposed. From these sections, samples were collected at depth about $0.5-1 \mathrm{~m}$ using a hand auger and scrapper. The collected samples were labeled and preserved in sample bags. 
The collected samples were washed carefully to remove the unwanted fraction of materials like clay and silt, dried in an oven at $100^{\circ} \mathrm{C}$ temperature for $30-40$ minutes, and $100 \mathrm{gm}$ of samples were weighted from oven dry samples for each and every location. Then, the samples were sieved for 15 to 20 minutes, and the samples were stored in individual packets after labeling the mesh number and retained weight.

After picking under a binocular microscope, foraminifera was placed on a gridded tray, observed under Leica EZ4E microscope (Leica Corporation) at 35X magnification, and bright-field images were captured using cellSens software (Leica). In order to accurately identify foraminifera species based on morphological features, some representative samples sent to Jadavpur University, India for Scanning Electron Microscopy (SEM).

\section{Systematic paleontology}

Taxonomic identification from Order to the Genus level was followed after Loeblich and Tappan (1988), Cushman (1933) and revised and uptodated by using some literature to identify upto species level (Akimoto et al. 2002, Barker 1960, Wells 1985, Nomura and Seto 1992, 2002, Kathal et al. 2000, Khare et al. 2007, Dey et al. 2007, 2012, Devi and Rajshekhara 2009, Ghosh 2012, Gehrels and Newman 2004, Edwards et al. 2004, Culver and Horton 2005, Javaux and Scott 2003, Horton and Edwards 2006 and Hawkes et al. 2010). The Foraminifera shells were identified based on the shape of the test, the number of chambers, nature of coiling, wall composition, type of aperture, etc.

Order: Rotaliida

Superfamily: Rotaliacea

Family: Rotaliidae Ehrenberg, 1839

Subfamily: Ammoniidae Saidova, 1981

Genus: Ammonia Brunnich, 1772

\section{Ammonia aoteanna (Plate 1: a, b)}

Morphological Description: Test biconvex with low trochospiral coil, spiral side evolute, umbilical side involute and may have large umbilical plug surrounded by umbilical fissure, wall calcareous, and coarsely perforate.

Observed Location: Jamtala and Kotka beach, Sundarbans.

\section{Ammonia beccarii (Plate 1: c, d)}

Morphological Description: Ammonia beccarii has resembles morphological features with Ammonia aoteanna, except both surfaces are ornamented by pillars, and the umbilical side has transverse ridges. 
Observed Location: Dimer char, Jamtala beach, Kochikhali and Kotka beach in the Sundarbans.

\section{Ammonia tepida (Plate 1: e, f)}

Morphological Description: Ammonia tepida has similar in morphological features with Ammonia aoteanna except for final whorl with deeply incised umbilical, radial and intraseptal spaces, sutural fissures straight or branching and appear on the umbilical side; wall calcareous, optically radial, primarily bilamellar, moderately perforate.

Observed Location: Jamtala beach, Sundarbans.

Genus: Asterorotalia Hofker, 1950

\section{Asterorotalia trispinosa (Plate 1: g, h)}

Morphological Description: Test flattened, low trochospiral to the nearly planispiral coil of two whorls, eight to ten chambers in the final whorl, sutures slightly depressed, chambers on umbilical side separated by deeply incised sutures with granulose to spinose borders; wall calcareous, perforate, optically radial, the surface of spiral side smooth between the numerous inflational knobs and pustules.

Observed Location: Dimer char, Jamtala beach and Kotka beach in the Sundarbans.

Superfamily: Discorbacea

Family: Rosalinidae Reiss, 1963

Genus: Rosalina d'Orbigny, 1826

\section{Rosalina sp. (Plate 1: i, j)}

Morphological Description: Test trochospiral, planoconvex to concavo-convex, on the umbilical side chambers, are subtriangular; wall calcareous, with organic inner lining and surface smooth.

Observed Location: Jamtala beach, Sundarbans.

\section{Rosalina bradyi (Plate 1: k, l)}

Morphological Description: Test trochospiral where the depressed sutures are oblique and curved back at the periphery, on the umbilical side chambers are subtriangular and strongly overlapping; wall calcareous.

Observed Location: Dimer char, Kochikhali, and Kotka beach in the Sundarbans. 
Order: Lituolida

Superfamily: Rzehakinacea Cushman

Family: Rzehakinidae Cushman

Genus: Miliammina Heron-Allen and Earland, 1930

\section{Miliammina fusca (Plate 1: m, n)}

Morphological Description: Test elongate ovate, with quinqueloculine arrangement; wall relatively thick, very finely agglutinated on an organic base; aperture at the end of the chamber, rounded to semilunate.

Observed Location: Jamtala beach, Sundarbans.

Order: Miliolida

Suborder: Miliolina

Superfamily: Miliolacea

Family: Miliolidae

Genus: Quinqueloculina d'Orbigny, 1826

$$
\text { Quinqueloculina akneriana (Plate 1: o, p) }
$$

Morphological Description: Exterior of the test is composed of three chambers, with early chamber quinqueloculine depending on the degree of overlap of successive chambers, the later ones making 120 degrees angle to each other; wall calcareous, imperforate, porcelaneous; aperture ovate typically with a bifid tooth.

Observed Location: Jamtala beach, Sundarbans.

Order: Lituolida

Superfamily: Lituolacea

Family: Haplophragmoididae Maync, 1952

Subfamily: Haplophragmoidinae Maync, 1952

Genus: Haplophragmoides Cushman, 1910

$$
\text { Haplophragmoides canariensis (Plate 1: q, r) }
$$

Morphological Description: Test planispirally enrolled, involute to slightly evolute, biumbilicate, wall thin, finely to coarsely agglutinated, exterior smoothly finished; aperture elongate equatorial silt at the base of the apertural face.

Remarks: It is commonly found in the high marsh area. 
Observed Location: Dimer char, Jamtala beach, Kochikhali and Kotka beach in the Sundarbans.

Order: Rotaliida

Family: Anomalinidae

Genus: Anomalinella

$$
\text { Truncatulina rostrata (Plate 1: s, t) }
$$

Morphological Description: Early-stage test in trochoid but in adult stage test is planispiral; nine to ten gradually enlarging chambers in the final whorl, sutures gently curved, limbate, periphery angular, carinate; wall calcareous, sutures and keels imperforate; aperture ventral.

Remarks: The subgenus Preanomalinella was described as slightly trochoid in the early stage and had a slightly asymmetrical aperture, but both features are present in the type species of Anomalinella sp. A. rostrata hence are regarded as congeneric.

Observed Location: Jamtala beach, Sundarbans.

Order: Trochamminida

Superfamily: Trochamminacea

Family: Trochamminidae

Subfamily: Trochammininae

Genus: Trochammina

\section{Trochammina inflata (Plate 2: a, b)}

Morphological Description: Test free, trochospiral, wall agglutinated, imperforate, aperture an interio-marginal, umbilical-extra umbilical arch with narrow bordering lip.

Observed Location: Jamtala beach and Kotka beach in the Sundarbans.

Order: Trochamminida

Superfamily: Trochamminacea

Family: Trochamminidae

Subfamily: Jadammininae Saidova, 1981

Genus: Jadammina Bartenstein and Brand, 1938 
Jadammina macrescens (Plate 2: c, d)

Morphological Description: Test free, a flattened trochospiral that tends to be nearly planispiral in the adult, chambers increasing gradually in size as added, sutures radial to slightly curved; primary aperture a low interiomarginal equatorial silt.

Observed Location: Jamtala beach and Kotka beach in the Sundarbans.

Order: Rotaliida

Superfamily: Rotaliacea

Family: Elphidiidae Galloway, 1933

Subfamily: Elphidiinae Galloway, 1933

Genus: Elphidium de Montfort, 1808

Elphidium lessonii (Plate 2: e, f)

Morphological Description: Test large, lenticular, planispirally enrolled, involute or partially evolute, may have an umbilical plug on each side, seven to twenty chambers in the final whorl, periphery carinate; wall calcareous, optically radial, finely perforate.

Observed Location: Dimer char, Jamtala beach, Kochikhali and Kotka beach in the Sundarbans.

Order: Rotaliida

Superfamily: Rotaliacea

Family: Elphidiidae Galloway, 1933

Subfamily: Elphidiinae Galloway, 1933

Genus: Cribroelphidium Cushman and Bronnimann, 1948

$$
\text { Cribroelphidium vadescens (Plate 2: } \mathrm{g}, \mathrm{h} \text { ) }
$$

Morphological Description: Test planispiral and involute with rounded noncarinate periphery, about eight to eleven slightly inflated chambers in the final whorl, slightly depressed, umbilicus with boss; wall calcareous, perforate but apertural face smooth, optically radial, bilamellar with septal flaps; aperture multiple and may also have areal openings.

Observed Location: Jamtala beach, Kochikhali and Kotka beach in the Sundarbans. 
Order: Rotaliida

Superfamily: Nonionacea

Family: Nonionidae Schultze, 1854

Subfamily: Nonioninae Schultze, 1854

Genus: Haynesina Banner and Culver, 1978

$$
\text { Nonionina germanica Ehrenberg, } 1840 \text { (Plate 2: i, j) }
$$

Morphological Description: Test planispiral, at least in the adult, involute, biumbilicate, about eight to ten chambers per whorl, chamber wall bend inward posteriorly and fuse to the preceding septal face; wall calcareous, perforate, optically radial but morphologically granular calcite, tubercles prominently developed around the aperture; primary aperture a low and symmetrical interiomarginal arch but obscured by abundant surface pustules.

Observed Location: Dimer char, Jamtala beach, Kochikhali and Kotka beach in the Sundarbans

Order: Rotaliida

Superfamily: Nonionacea

Family: Nonionidae Schultze, 1854

Subfamily: Nonioninae Schultze, 1854

Genus: Nonionella Cushman, 1926

Nonionella miocenica Cushman, 1926 (Plate 2: k, 1)

Morphological Description: Test slightly compressed in a low trochospiral coil, periphery rounded, spiral side partially evolute around an umbilical boss, umbilical side involute, chambers numerous, broad and low, whorls progressively enlarging and may produce a flaring test, chambers with a flaplike projection overhanging the umbilicus, sutures curved, depressed; wall calcareous, aperture a small interiomarginal and nearly equatorial arch.

Observed Location: Dimer char, Jamtala beach and Kotka beach in the Sundarbans.

Order: Rotaliida

Superfamily: Nonionacea

Family: Nonionidae Schultze, 1854

Subfamily: Nonioninae Schultze, 1854

Genus: Nonionellina Voloshinova, 1958 
Nonionellina sp (Plate 2: $\mathrm{m}, \mathrm{n}$ )

Morphological Description: Test trochospiral in the early stage, later nearly planispiral, involute, chambers enlarging rapidly as added, with an inflated basal lobe on the umbilical side, biumbilicate but umbilici small and inequal, open throughout growth and not covered with chamber lobes, periphery subangular to rounded; wall calcareous, finely perforateS; primary aperture a low interiomarginal and equatorial arch.

Observed Location: Dimer char and Kochikhali in the Sundarbans.

\section{Discussion}

Through this study, 17 species, 14 genera representing 9 families of foraminifera were identified. According to their origin, the identified species are benthic in origin. The most significant and remarkable genera are Nonionina, Nonionella, Ammonia, Elphidium, Rosalina, Haplophragmoides, Jadammina, Trochammina, Cribroelphidium, Asterorotali $a$.

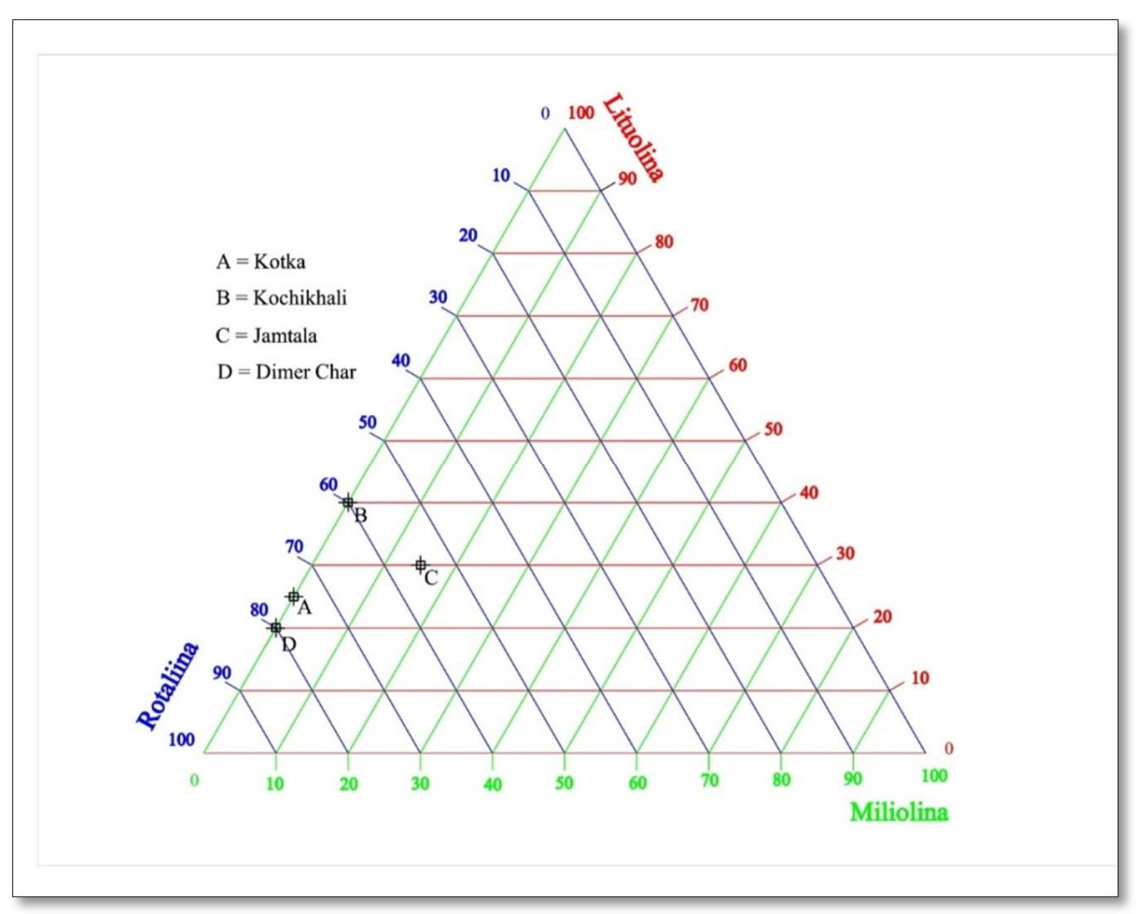

Fig. 2. Ternary plot characterizing sampling sites based on observed suborder of forams. 
Quinqueloculina, Miliammina etc. Among the three major suborders, Rotaliina comprises the highest number of foraminifera. The suborder Lituolina contains a fair amount of forams. Mainly, Rotaliina and Lituolida cover the whole Kotka, Kochikhali and Dimer char and only Jamtala contains a little amount of forams of suborder Miliolina containing only 1 species namely Quinqueloculina akneriana. The ternary plot can show the relative abundance based on the percentage of the observed suborders of foraminifera, and it characterizes sampling sites.

Based on the tidal sequence, the Sundarbans is recognized as high, middle and low marsh zone. Based on the frequency of occurrence of an individual species in samples from a particular location, the relative abundance curves of species are prepared for four study sites.

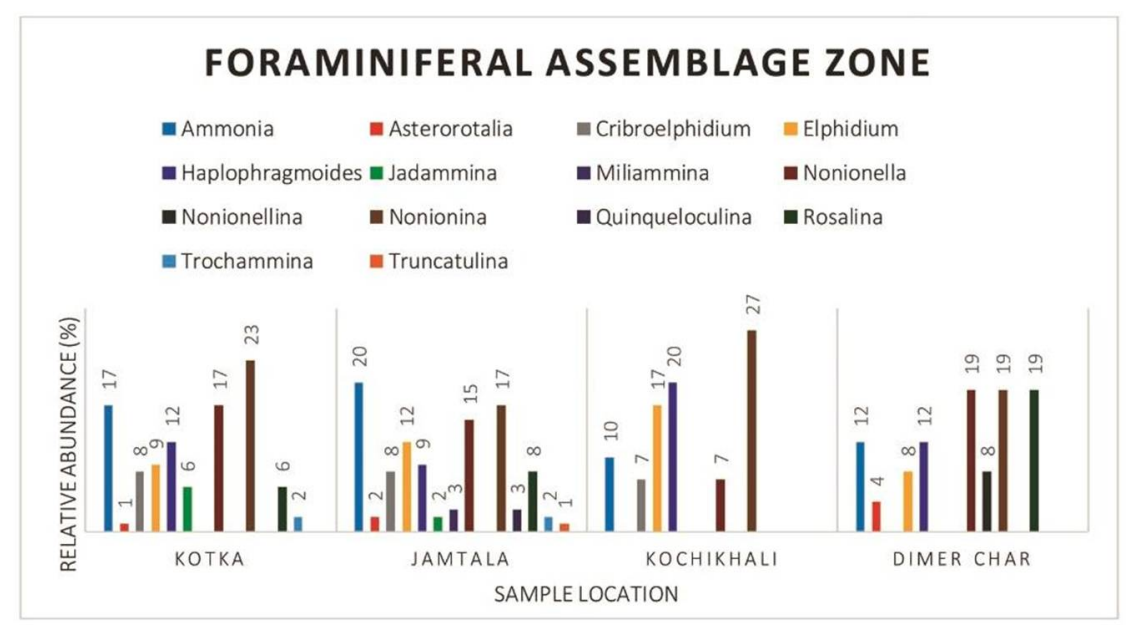

Fig. 3. Foraminiferal assemblage zones for the study area.

From Fig. 3, Kotka beach can be recognized as Nonionina assemblage zone, Jamtala beach designated as Ammonia assemblage zone. In contrast, Kochikhali can be demarcated as the Nonionina assemblage zone and Dimer char as the RosalinaNonionina-Nonionella assemblage zone.

In the present research, calcareous taxa such as Nonionina germanica, Nonionella miocenica, Ammonia beccarii, Elphidium lessonii, Rosalina bradyi, Cribroelphidium vadescens etc. found most based on their relative abundance. According to Murray (1999, 2006), Ammonia and Elphidium are frequently dominant modern foraminiferal assemblages in the lower zone of estuaries. Based on the determination of high marsh 
assemblages, the pioneer works of many scientists have depicted the distribution patterns of modern saltmarsh agglutinated foraminifera, they established their utility already in assessing paleo sea level. Agglutinated foraminifera such as Haplophragmoides canariensis, Jadammina macrescens, Trochammina inflate, Miliammina fusca, etc. have been identified in the study area. Finally, both calcareous and agglutinated foraminifera are abundant in the middle marsh zone.

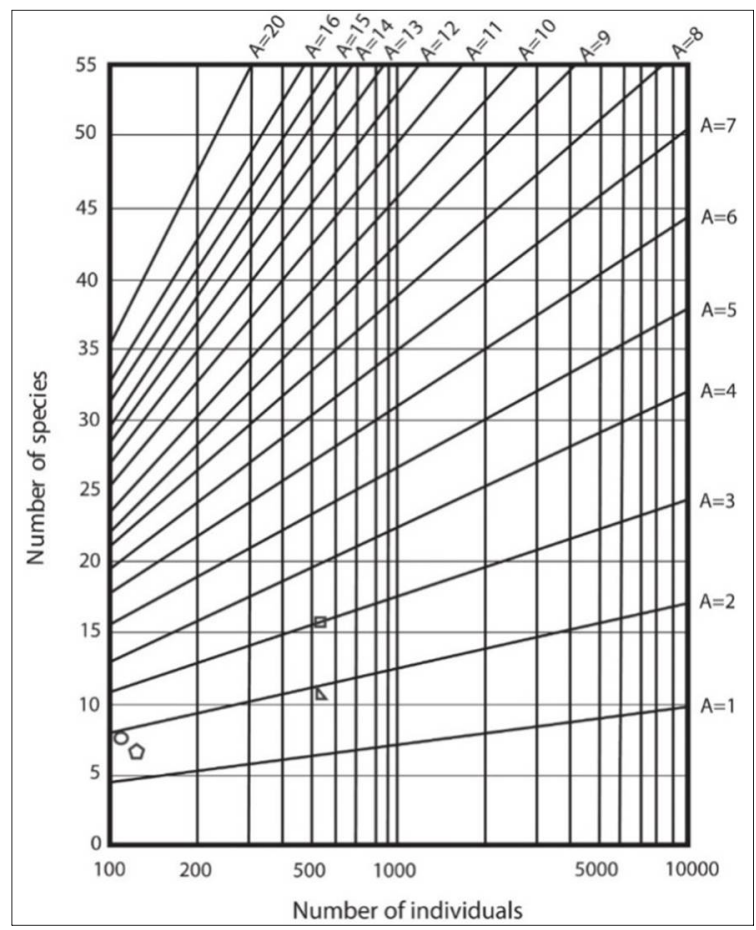

Fig. 4. Diversity index (A) of the Sundarban foraminiferal assemblage (symbol code: triangle - Kotka; square - Jamtala; pentagon - Kochikhali and circle - Dimer Char).

In Kotka, calcareous foraminiferal assemblages Nonionina, Nonionella, Ammonia are abundant and characterize Kotka beach as a low marsh zone of depositional environments. The abundance of calcareous and agglutinated foraminifera characterized Jamtala as the middle marsh zone of deposition. Finally, in Kochikhali and Dimer char, the calcareous foraminiferal assemblages like Nonionina germanica, Elphidium lessonii, Rosalina bradyi, Ammonia beccarii, Cribroelphidium vadescens, Nonionellina sp. dominate in low marsh zone and agglutinated foraminiferal assemblage 
Haplophragmoides canariensis is dominant in high marsh zone (Gupta 1999, Murray 1999b, Ghosh 2014). So, Kochikhali and Dimer char are demarcated as low to high marsh zone of depositional environments.

Foraminiferal assemblages are low diverse in Sundarban and Kotka and Jamtala contain 11 and 16 species, respectively. Kochikhali and Dimer char are diverse in nature and include 7 and 8 species, respectively. So, both zones suggest that the foraminifera decrease from low to high marsh zone (Fig. 4).

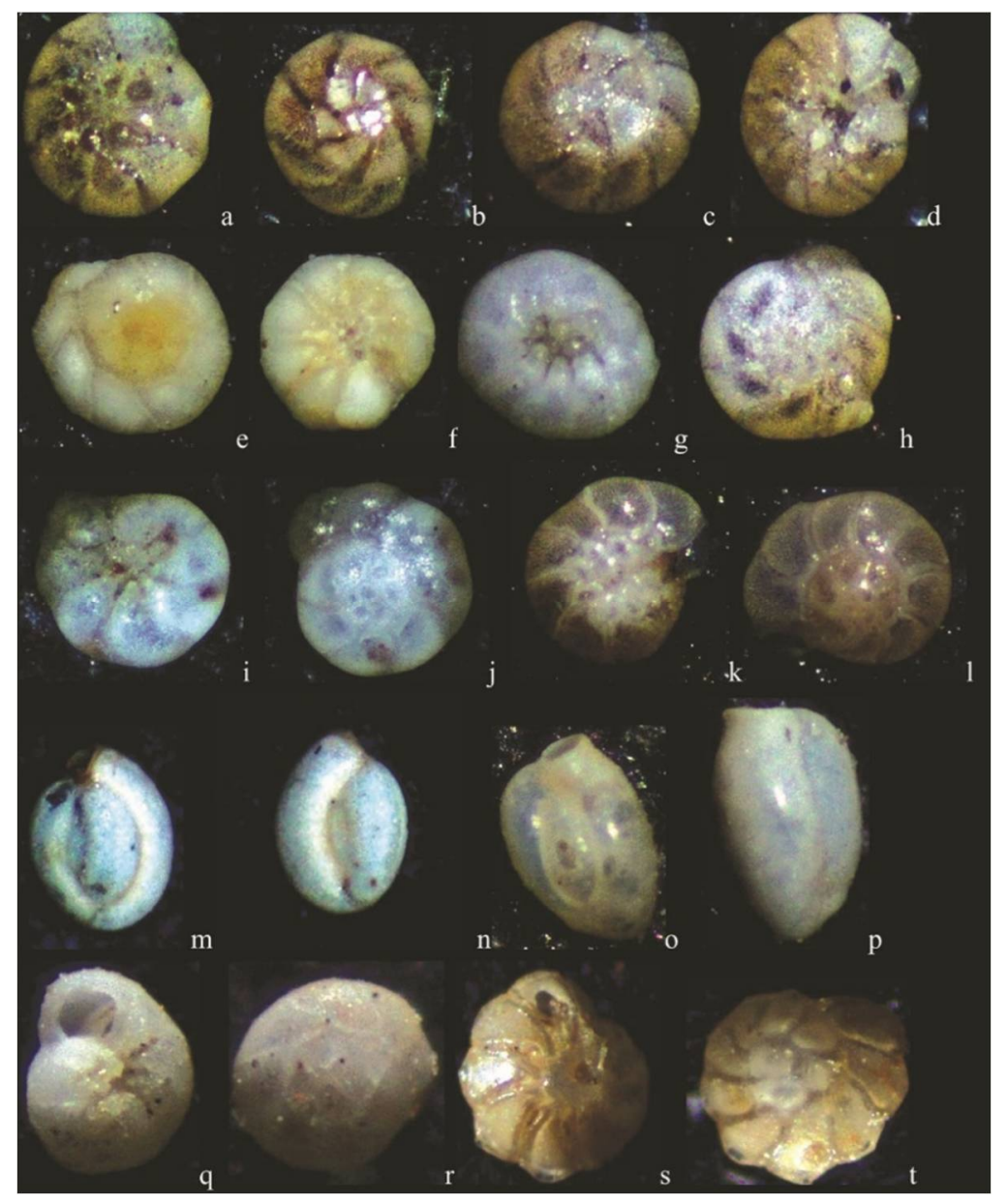

Plate 1: a, b Ammonia aoteana, c. d Ammonia beccarii, e. f Ammonia tepida, g, h. Asterorotalia trispinosa, i, j. Rosalina sp., k, l. Rosalina bradyi, m, n. Miliammina fusca, o, p. Quinqueloculina akneriana, q, r. Haplophragmoides canariensis, s, t. Truncatulina rostrata. 


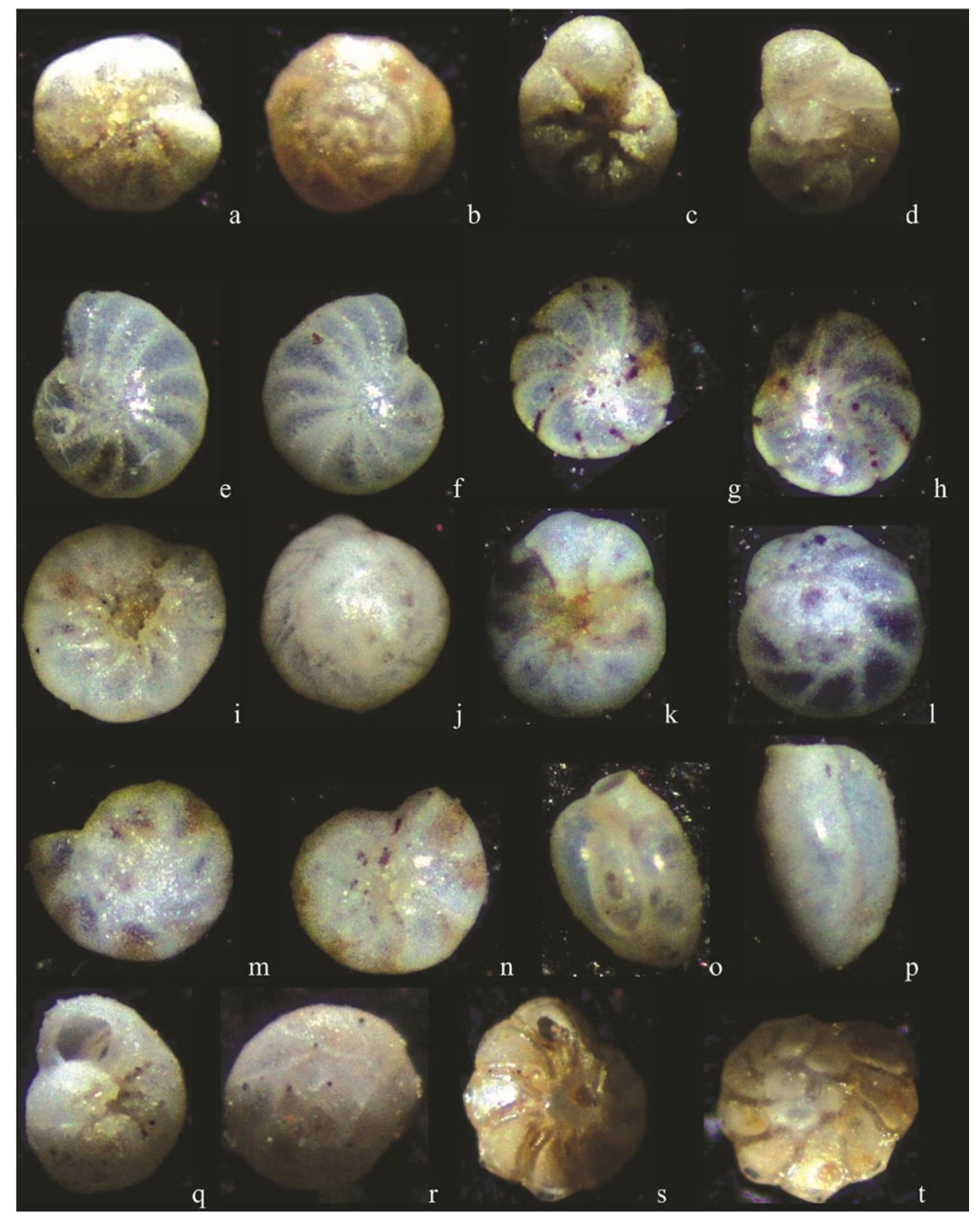

Plate 2: a, b Trochammina inflata, c, d. Jadammina macrescens, e, f. Elphidium lessonii, g, h, Cribroelphidium vadescens, i, j. Nonionina germanica, $\mathbf{k}, \mathbf{l}$. Nonionella miocenica, $\mathrm{m}, \mathrm{n}$. Nonionellina sp. o, p, Quinqueloculina akneriana. q, r, Haplophragmoides canariensis, s, t. Truncatulina rostrata. 


\section{Conclusion}

The marsh areas of Sundarban are influenced by a multitude of factors comprising monsoon, meso-tidal range, and biotic effects. These environmental factors have a marked effect on foraminiferal assemblage and mangrove vegetation. The present integrated study of foraminifera and vegetation distinguishes the high and low marsh zones: a) High Marsh: Foraminifera- Trochammina inflata, Miliammina fusca, and Haplophragmoides canarienses; b) Low marsh: Foraminifera-Ammonia beccarii, Haynesina germanica, Rosalina bradyi and Elphidium sp. Saltmarsh foraminifera differentiates the high and low marsh zone, and paleo-environment of the study area has been identified. Numerous environmental factors influence and these factors take prominent attributes on foraminiferal assemblages. The dominance of high marsh foraminifera like Haplophragmoides canariensis, Jadammina macrescens, Trochammina inflata and Miliammina fusca is a distinguished feature, and in fact, Jadammina and Trochammina are confined to mangrove habitats (Murray 2006). This research aimed to create a thorough study of benthic foraminifera from remote, inaccessible, and unexplored Sundarbans of Bangladesh. This foraminiferal dataset may provide a better understanding of sea level rise in the south-western coastal region of Bangladesh.

\section{References}

Akimoto, K.M. 2002. Atlas of Holocene benthic foraminifers of Shimabara bay, Kyushu, Southwest Japan. The Kagoshima Univ. Mus. Mon. 2: 1-112.

Culver, S.J. and B.J. Horton. 2005. Infaunal marsh foraminifera from the outer banks, North Carolina, U.S.A. J. Foram. Res. 35(2): 148-170.

Cushman, J.1. 1933. Foraminifera their classification and economic use. Special Publication. No. 4. Cushman Laboratory for Foraminiferal Research.

Devi, G.S. and K.P. Rajshekhara. 2009. Intertidal Foraminifera of Indian coast-a scanning electron photomicrograph-illustrated catalogue. J. Threatened Taxa. 1(1):17- 36.

Dey, M., D. Ganguly, S.K. Mandal, T.K. De and T.K. Jana. 2007. Foraminiferal calcium carbonate pump response to temporal changes of carbon dioxide systems in the Sundarban mangrove environment North East coast of Bay of Bengal India. Amer. Geophys. Union. V. 114: 32-45.

Dey, M., Ganguly, D., Choudhury, C., Majumder, N. and Jana, T.K. 2012. Intra-annual variation of modern foraminiferal assemblage in a tropical mangrove ecosystem in India. Wetlands. 32(5): 813-826.

Edwards, R.J. 2004. Surface distributions of salt-marsh foraminifera from Connecticut, USA: modern analogues for high-resolution sea level studies. Marine Micropaleontology. 51(1-2): 1-21.

Flint, J.M. 1899. Recent Foraminifera: A descriptive catalogue of specimens dredged by the US Fish Commission Steamer Albatross. Smithsonian Institution. United States National Museum. 
Gehrels, W.R. and S.W.G. Newman. 2004. Salt-marsh foraminifera in Ho Bugt, western Denmark, and their use as sea-level indicators. Geografisk Tidsskrift-Danish J. Geogr. 104(1): 97-106.

Ghosh, A. 2012. Estuarine Foraminifera from the Gulf of Cambay. J. Geolog. Soc. India. 80(1): 65-74.

Ghosh, A. 2014. Marsh foraminiferal assemblages in relation to vegetation in Sunderban, India. $J$. Geol. Soc. India. 84(6): 657-667.

Gupta, B. K. 1999a. Systematics of modern Foraminifera. In Modern foraminifera. Springer, Dordrecht. pp. 7-36.

Gupta, B.K. 1999b. Foraminifera in marginal marine environments. In Modern foraminifera. Springer, Dordrecht. pp. 141-159.

Hawkes, A.D. 2010. The application of intertidal foraminifera to reconstruct coastal subsidence during the giant Cascadia earthquake of AD 1700 in Oregon, USA. Quaternary International. 221(1-2):116-140.

Horton, B.P. 2006. Quantifying Holocene sea level change using intertidal foraminifera: lessons from the British Isles. Departmental Papers (EES). 50: 1-97.

Javaux, E.J. 2003. Illustration of modern benthic foraminifera from Bermuda and remarks on distribution in other subtropical/tropical areas. Palaeontologia Electronica. 6(4): 29-57.

Kathal, P.K. 2002. Taxonomy, distribution patterns and ecology of recent littoral foraminifera of the east coast of India. Neues Jahrbuch für Geologie und Paläontologie-Abhandlungen. $115-160$

Khare, N. C. 2007. An overview of foraminiferal studies in nearshore regions off eastern coast of India, and Andaman and Nicobar Islands. Indian Jour. Mar. Sci. 36: 288-300.

Loeblich, A. R. and Tappan, H. 1988. Foraminiferal Genera and their Classification. Van Nostrand Reinhold, New York Google Scholar.

Mitra, A.G. 2009. Observed changes in water mass properties in the Indian Sundarbans (northwestern Bay of Bengal) during 1980-2007. Curr. Sci. 97(10): 1445-1452.

Murray, J.W. 1999a. Natural dissolution of modern shallow water benthic foraminifera: taphonomic effects on the palaeoecological record, Jour. Palaeogeography, Palaeoclimatology, Palaeoecology. 146 (1-4): 195-209.

Murray, J.W. 1999b. Taphonomic experiments on marginal marine foraminiferal assemblages: how much ecological information is preserved? Jour. Palaeogeography, Palaeoclimatology, Palaeoecology. 149(1-4): 183-197.

Murray, J.W. 2006. Ecology and applications of benthic foraminifera. Cambridge University Press.

Sen, A.G. 2016. Modern benthic foraminiferal assemblages from the world's largest deltaic mangrove ecosystem, the Sundarbans. Marine Biodiversity. 46(2): 421-431.

Stanley, D.J. and A.K. Hait. 2000. Holocene depositional patterns, neotectonics and Sundarban mangroves in the western Ganges-Brahmaputra delta. J. Coastal Res. 16(1): 26-39.

(Revised copy received on 16.09.2021) 